\title{
THE GLOBAL EVOLUTION OF DEEP VEIN THROMBOSIS PUBLICATIONS: A BIBLIOMETRIC ANALYSIS
}

\section{Derin Ven Trombozu Yayınlarının Küresel Evrimi: Bibliyometrik Bir Analiz}

\author{
Sertan ÖZYALÇIN ${ }^{1}$ (D), Mehmet Emir EROL ${ }^{1}$
}

${ }^{1}$ Hitit Üniversitesi Kalp ve Damar Cerrahisi Anabilim Dall, ÇORUM, TÜRKIYYE

\author{
ABSTRACT

Objective: Deep vein thrombosis (DVT) is a major global health problem, especially in elderly population, no comprehensive bibliometric study that evaluates publications on this topic in a holistic manner has been reported in the literature In this study, it was aimed to determine the current issues and the highest impact studies as well as to reveal the scientific outcomes on DVT in a holistic manner with bibliometric and statistical analyses.

Material and Methods: All publications on DVT indexed in the Web of Science database between 1980 and 2020 were analyzed using bibliometric and statistical methods. Relationships between DVT publication productivity and certain economic development indicators of countries in the world were investigated with the Spearman's correlation coefficient. Regression analysis was used to estimate the number of publications in the coming years.

Results: A total of 10414 publications including 5890 articles were found. The top three productive countries in DVT were USA $(1773,30.1 \%)$, UK $(427,7.3 \%)$, and Germany (412, 7\%). McMaster University (141), Harvard University (104), and University of Amsterdam (99) were the leading institutions. The top three journals have published the highest numbers of articles were Thrombosis and Haemostasis (235), Thrombosis Research (185), and Journal of Vascular Surgery (152)

Conclusion: We shared a summary of 5890 articles in this comprehensive bibliometric study on deep vein thrombosis. The most cited and co-cited articles and high-impact journals that should be evaluated on deep vein thrombosis are summarized. This study will be a useful guide for scientists and clinicians on the global consequences of deep vein thrombosis.

Keywords: Deep vein thrombosis, deep venous thrombosis, bibliometric analysis, citation analysis, trend topics
Amaç: Derin ven trombozu özellikle yaşlı popülasyonda önemli bir küresel sağlık sorunudır ve literatürde bu konudaki yayınları bütüncül olarak değerlendiren kapsamlı bir bibliyometrik çalışma bildirilmemiştir. $\mathrm{Bu}$ çalışmada, bibliyometrik ve istatistiksel analizler ile derin ven trombozu ile ilgili bilimsel sonuçların bütüncül bir şekilde ortaya konarak, güncel konuların ve etkisi en yüksek çalışmaların belirlenmesi amaçlanmıştır.

Gereç ve Yöntemler: Web of Science veri tabanında 1980 ile 2020 yılları arasında indekslenen derin ven trombozu ile ilgili tüm yayınlar bibliyometrik ve istatistiksel yöntemler kullanılarak analiz edildi. Derin ven trombozu yayın verimliliği ile dünyadaki ülkelerin belirli ekonomik gelişmişlik göstergeleri arasındaki ilişkiler Spearman korelasyon katsayısı ile incelenmiştir. Gelecek yıllardaki yayın sayısını tahmin etmek için regresyon analizi kullanılmıştır.

Bulgular: Derin ven trombozu ile ilgili 5890 tanesi makale olmak üzere toplam 10414 yayın bulundu. Derin ven trombozu konusunda ilk üç üretken ülke ABD (1773, \%30.1), İngiltere (427, \%7.3) ve Almanya (412, \%7) idi. McMaster Üniversitesi (141), Harvard Üniversitesi (104) ve Amsterdam Üniversitesi (99) önde gelen kurumlardi. En fazla makale yayınlayan ilk üç dergi, Thrombosis and Haemostasis (235), Thrombosis Research (185), and Journal of Vascular Surgery (152) olmuştur.

Sonuç: Derin ven trombozu (DVT) özellikle yaşlı popülasyonda önemli bir küresel sağlık sorunudır ve literatürde bu konudaki yayınları bütüncül olarak değerlendiren kapsamlı bir bibliyometrik çalışma bildirilmemiştir. $\mathrm{Bu}$ çalışmada, bibliyometrik ve istatistiksel analizler ile DVT ile ilgili bilimsel sonuçların bütüncül bir şekilde ortaya konarak, güncel konuların ve etkisi en yüksek çalışmaların belirlenmesi amaçlanmıştır.

Anahtar Kelimeler: Derin ven trombozu, derin venöz tromboz, bibliyometrik analiz, alıntı analizi, trend konular 


\section{INTRODUCTION}

Deep vein thrombosis (DVT) is a blood clot that usually occurs in the deep veins of the lower extremities and rarely in the upper extremities, pelvis and other veins. Virchow has defined the basis of the pathogenesis of venous thromboembolism (VTE), which is considered to be a result of the triple phenomena of stasis of blood flow, endothelial injury, and hypercoagulability $(1,2)$. The primary risk factors for thrombosis include advanced age, immobility, obesity, varicose veins, history of thrombosis, pregnancy/puerperium, postmenopausal hormone therapy, surgery, cancer, genetic factors affecting the coagulation balance (anticoagulant deficiencies, factor $\mathrm{V}$ Leiden, and prothrombin 20210A mutations), trauma/injury, and hospitalization (3). DVT is the third most common cause of death. Even in patients without pulmonary embolism, recurrent thrombosis and post-thrombotic syndrome are a significant cause of morbidity (4). The primary complications of DVT include pulmonary embolism, post-thrombotic syndrome, and bleeding due to the use of anticoagulants. Although there are often no complications in the prognosis of DVT, post-thrombotic syndrome may occur at a rate of $43 \%$ within two years after DVT. Moreover, $\sim 6 \%$ of DVT cases lead to death within a month after the diagnosis. Despite developments in medicine, the gold standard method of treatment in DVT is anticoagulant therapy (4). The incidence of DVT varies among ethnic groups (5). There is evidence that the incidence of DVT and the risk of complications are higher in African Americans and in the Caucasians compared with Spaniards and Asians $(4,6)$. In different studies, it has been stated that the incidence of DVT varies between 43.7 and 145.0 per 100,000 population $(5,7)$.

Bibliometry is the statistical analysis of scientific publications such as articles and books $(8,9)$. Owing to the increasing number of publications in the literature, the value of bibliometric analyses is constantly increasing (10). Because of bibliometric analyses, researchers can save time on literature review and access a summary of thousands of scientific outcomes in a short time (11). Bibliometric studies reveal the highest impact publications, collaborations between countries, authors and institutions, and active journals on a particular topic $(12,13)$. Furthermore, bibliometric studies reveal past and current trends and provide researchers with new ideas and different perspectives $(14,15)$. Although the number of studies on DVT, is on the increase, no bibliometric study that evaluates the publications on this topic has been reported in the literature. In this study, it was aimed to evaluate the scientific outcomes on DVT between 1980 and 2020 with bibliometric and statistical analyses to determine the current issues and the highest impact studies and to reveal collaborations between countries.

\section{MATERIALS AND METHODS}

A literature review was performed using the keywords "deep vein thrombosis", "deep venous thrombosis", "deep vein thromboses", and "deep venous thromboses" in the "title" section of publications. Based on this search method, all publications on DVT in the Web of Science (WoS) database were downloaded (access date: 01.12.2020) and analyzed using bibliometric and statistical methods. The VOSviewer (Version 1.6.15, Leiden University's Centre for Science and Technology Studies) was used for bibliometric network visualizations (16). The website (http://lert.co.nz/map/) was used for drawing a world map. SPSS (Version 22.0, SPSS Inc., Chicago, IL, USA, license: Hitit University) was used for statistical analyses. The normality of the distribution of data was tested using the KolmogorovSmirnov test. Correlation analyses between the number of articles on DVT produced by countries and certain indicators of economic development in the countries of the world were performed using Spearman's correlation coefficient according to the data distribution. Linear 
regression analysis was used to estimate the number of publications to be made in the coming years. $\mathrm{P}<0.05$ was considered to indicate a statistically significant difference. Abstract sections of all studies were read and the studies were divided into 5 groups as epidemiology, surgery, prophylaxis, anticoagulation (medical treatment) and diagnosis. The medical treatment group was divided into 4 groups as heparins, warfarin, new oral anticoagulants, and thrombolytic-fibrinolytic treatments. The study numbers of the groups were examined.

\section{RESULTS}

\section{General Features and Global Productivity}

Total of 10414 publications on DVT that were published between 1980 and 2020 were identified. These publications included the following publication types: original article $(5890,56.5 \%)$, meeting abstract (2399, $23.0 \%$ ), letter $(864,8.2 \%)$, proceedings paper (504, $4.8 \%$ ), editorial material (492, 4.7\%), review (458, $4.3 \%)$, and others $(271,2.1 \%)$. Bibliometric analyses were conducted with 5890 studies published in the category of articles. Of the 5890 articles, 5362 (91\%) were in English and the rest were in German (256), French (165), Spanish (55), Turkish (20), Russian (8), Italian (5), Korean (5), Polish (4), Portuguese (2), Chinese (1), Czech (1), Dutch (1), Hungarian (1), Japanese (1), Serbo Croatian (1), Slovenian (1), and Ukrainian (1). H-index of 5890 articles was 162 and the total number of citations the articles received was 163377 (without self-citations: 131601). The average number of citations received per article was 27.74 .

\section{Development of Publications}

Figure 1 shows the distribution of published articles by years. Moreover, the results of linear regression analysis used to estimate the publications for the next 10 years (2021-2030) have been added to Figure 1 along with the regression curve. It has been estimated as per the regression analysis results that 248 articles on DVT will be published in 2021 (CI 95\%: 213-282) and 290 articles on DVT will be published in 2030 (CI 95\%: 254-327) (Figure 1).

\section{Active Areas of Research}

The top 15 research areas with the highest numbers of studies on DVT were Cardiovascular System Cardiology (1932, 32.8\%), Surgery (1225, 20.8\%), General Internal Medicine (1155, 19.6\%), Hematology (1118, 18.9\%), Radiology Nuclear Medicine Medical Imaging (455, 7.7\%), Orthopedics (369, 6.2\%), Research Experimental Medicine (176, 3\%), Neurosciences Neurology (146, 2.5\%), Pharmacology Pharmacy (144, 2.4\%), Respiratory System (124, 2.1\%), Emergency Medicine (122, 2.1\%), Obstetrics Gynecology (117, 2\%), Sport Sciences (97, 1.6\%), Oncology (90, 1.5\%), and Rehabilitation $(85,1.4 \%)$.

\section{Active Countries}

The articles contained addresses in 105 different countries. Figure 2 shows the distribution of the countries of the world that produced the articles. The top 16 countries that produced the highest numbers of publications (>100 articles) among these countries were USA $(1773,30.1 \%)$, UK (427, 7.3\%), Germany (412, $7 \%)$, China (401, 6.8\%), Italy (363, 6.2\%), Canada (357, $6.1 \%)$, France $(331,5.6 \%)$, The Netherlands $(292,5 \%)$, Japan (280, 4.8\%), Sweden (195, 3.3\%), Switzerland $(185,3.1 \%)$, Spain $(170,2.9 \%)$, Turkey $(165,2.8 \%)$, Australia (118, 2\%), India (112, 1.9\%), and South Korea $(105,1.8 \%)$. The international collaboration network visualization map between 49 countries that produced at least 10 articles and collaborated among 105 countries that produced publications and the density map are presented with Figure 3a and 3b, respectively.

\section{Active Authors}

The top 10 active authors who made the highest numbers of publications on DVT were Buller HR (68), Prandoni P (68), Wells PS (51), Goldhaber SZ (49), Lensing 
AWA (46), Ginsberg JS (44), Kahn SR (43), Comerota AJ (41), Hirsh J (39), and Stein PD (37).

\section{Active Institutions}

The top 10 active instutions producing more than 40 publications on DVT were McMaster University (141), Harvard University (104), University of Amsterdam (99), University of Michigan (72), University of Ottawa (64), University of Padua (59), McGill University (50), Leiden University (49), Duke University (44), and Washington University (41).

\section{Active Journals}

Table 1 shows the top 51 active journals that published 20 and more articles on DVT, the total numbers of citations received by the journals, and the average number of citations received per article. Figure 4 shows there were a total of 1301 journals that published articles on DVT and the citation network visualization map between 51 journals that published at least 20 articles among these journals.

\section{Citation Analysis}

The top 20 articles that received the highest numbers of citations based on the total number of citations among 5890 articles, which were analyzed bibliometrically in the period 1980-2020, are given in Table 2. Furthermore, the average numbers of citations received by the articles per year are shown in the last column of Table 2.

\section{Co-citation Analysis}

Total of 55072 publications cited in the references sections of 5890 articles that were analyzed. Nine studies that received at least 200 co-citations among these publications were the studies by Rabinov (1972) (Number of co-citations: 313), Lensing (1989) (300), Prandoni (1996) (296), Anderson (1991) (248), Wells (1997) (235), Mewissen (1999) (217), Koopman (1996)
(209), Kearon (2012) (206), and Levine (1996) (200) $(7,17-24)$.

\section{Trend topics}

In 5890 articles published on DVT, 4985 keywords were used. The most used (in at least 20 different articles) 69 keywords among these keywords are shown in Table 3. Figure 5 shows the cluster analysis between these keywords. Figure 6.a shows the trend network visualization map and the citation network visualization map in Figure 6.b. When the studies on DVT were examined in groups (epidemiology, surgery, prophylaxis, anticoagulation, and diagnosis), it was observed that while the number of studies was similar between the groups in the early $80 \mathrm{~s}$, the number of studies on the diagnosis of DVT increased in the 90s. Looking at the 2000s, it was observed that more studies were conducted on the medical treatment of DVT. It has been observed that there has been a significant increase in the number of epidemiological studies on DVT from 2000 to 2020. (Figure 7a). In the study group in which the medical treatment of DVT was examined, it was observed that more studies were conducted on heparins from the beginning of the 80 s to the end of the 2000 s, while a significant increase was observed in the number of studies on thrombolytic-fibrinolytic treatments after the 2000s. It has been observed that there has been an increase in studies on new oral anticoagulants since 2015. It was observed that the number of studies on NOACs after 2018 exceeded the number of studies on warfarin (Figure 7b).

\section{Correlation Analysis}

There was a statistically significant correlation between the number of publications on DVT produced by the countries and GDP (Gross Domestic Product) and Gross Domestic Product (at purchasing power parity) per capita (GDP PPP) $(\mathrm{r}=0.722 \mathrm{p}<0.001 ; \mathrm{r}=0.707, \mathrm{p}$ $<0.001)$. 
Table 1: Top 51 journals publishing the most articles on deep vein thrombosis and citation analysis

\begin{tabular}{|c|c|c|c|c|c|c|c|}
\hline Journals & $\mathbf{R C}$ & $\mathbf{C}$ & $\mathbf{A C}$ & Journals & $\mathbf{R C}$ & $\mathbf{C}$ & $\mathbf{A C}$ \\
\hline Thrombosis and Haemostasis & 235 & 12937 & 55.1 & Blood & 32 & 2926 & 91.4 \\
\hline Thrombosis Research & 185 & 3687 & 19.9 & Journal of Arthroplasty & 32 & 547 & 17.1 \\
\hline Journal of Vascular Surgery & 152 & 6357 & 41.8 & British Journal of Haematology & 30 & 1403 & 46.8 \\
\hline $\begin{array}{l}\text { Journal of Thrombosis and } \\
\text { Haemostasis }\end{array}$ & 117 & 5397 & 46.1 & $\begin{array}{l}\text { Journal of Bone and Joint } \\
\text { Surgery-British Volume }\end{array}$ & 30 & 1843 & 61.4 \\
\hline $\begin{array}{l}\text { Clinical and Applied Thrombosis- } \\
\text { Hemostasis }\end{array}$ & 92 & 724 & 7.9 & Lancet & 30 & 7718 & 257.3 \\
\hline Blood Coagulation \& Fibrinolysis & 86 & 1077 & 12.5 & $\begin{array}{l}\text { American Journal of } \\
\text { Roentgenology }\end{array}$ & 29 & 1176 & 40.6 \\
\hline Phlebology & 79 & 367 & 4.6 & Circulation & 29 & 4073 & 140.4 \\
\hline Annals of Vascular Surgery & 76 & 599 & 7.9 & $\begin{array}{l}\text { Clinical Orthopaedics and Related } \\
\text { Research }\end{array}$ & 28 & 653 & 23.3 \\
\hline Archives of Internal Medicine & 70 & 14461 & 206.6 & Medicine & 27 & 106 & 3.9 \\
\hline International Angiology & 66 & 1011 & 15.3 & Orthopedics & 27 & 218 & 8.1 \\
\hline $\begin{array}{l}\text { Journal of Vascular Surgery- } \\
\text { Venous and Lymphatic Disorders }\end{array}$ & 61 & 346 & 5.7 & American Surgeon & 26 & 476 & 18.3 \\
\hline $\begin{array}{l}\text { Journal of Thrombosis and } \\
\text { Thrombolysis }\end{array}$ & 57 & 702 & 12.3 & $\begin{array}{l}\text { Journal of Trauma-Injury } \\
\text { Infection and Critical Care }\end{array}$ & 25 & 1110 & 44.4 \\
\hline Angiology & 54 & 738 & 13.7 & $\begin{array}{l}\text { International Journal of Clinical } \\
\text { and Experimental Medicine }\end{array}$ & 25 & 13 & 0.5 \\
\hline $\begin{array}{l}\text { Seminars in Thrombosis and } \\
\text { Hemostasis }\end{array}$ & 50 & 901 & 18.0 & $\begin{array}{l}\text { Archives of Physical Medicine } \\
\text { and Rehabilitation }\end{array}$ & 24 & 552 & 23.0 \\
\hline $\begin{array}{l}\text { Vasa-Journal of Vascular } \\
\text { Diseases }\end{array}$ & 50 & 420 & 8.4 & $\begin{array}{l}\text { Pulmonary Embolism, 2nd } \\
\text { Edition }\end{array}$ & 24 & 10 & 0.4 \\
\hline $\begin{array}{l}\text { Journal of Bone and Joint } \\
\text { Surgery-American Volume }\end{array}$ & 47 & 3154 & 67.1 & Acta Chirurgica Scandinavica & 23 & 563 & 24.5 \\
\hline Radiology & 45 & 4071 & 90.5 & American Journal of Hematology & 23 & 445 & 19.3 \\
\hline American Journal of Surgery & 43 & 1720 & 40.0 & $\begin{array}{l}\text { New England Journal of } \\
\text { Medicine }\end{array}$ & 23 & 9806 & 426.3 \\
\hline Annals of Internal Medicine & 43 & 8279 & 192.5 & Clinical Radiology & 22 & 443 & 20.1 \\
\hline $\begin{array}{l}\text { European Journal of Vascular and } \\
\text { Endovascular Surgery }\end{array}$ & 43 & 1070 & 24.9 & Surgery & 22 & 1181 & 53.7 \\
\hline $\begin{array}{l}\text { Journal of Vascular and } \\
\text { Interventional Radiology }\end{array}$ & 40 & 2212 & 55.3 & Acta Medica Scandinavica & 21 & 859 & 40.9 \\
\hline American Journal of Medicine & 38 & 2170 & 57.1 & $\begin{array}{l}\text { Deutsche Medizinische } \\
\text { Wochenschrift }\end{array}$ & 21 & 127 & 6.0 \\
\hline British Journal of Surgery & 38 & 2028 & 53.4 & British Medical Journal & 20 & 1893 & 94.7 \\
\hline Haemostasis & 37 & 1509 & 40.8 & $\begin{array}{l}\text { Cardiovascular and Interventional } \\
\text { Radiology }\end{array}$ & 20 & 328 & 16.4 \\
\hline Journal Des Maladies Vasculaires & 37 & 190 & 5.1 & $\begin{array}{l}\text { Journal of Ultrasound in } \\
\text { Medicine }\end{array}$ & 20 & 550 & 27.5 \\
\hline Chest & 36 & 2225 & 61.8 & & & & \\
\hline
\end{tabular}

RC: Record Count, C: Number of Citation, AC: Average Citation Per Document 
Table 2: The 20 most cited articles on deep vein thrombosis

\begin{tabular}{|c|c|c|c|c|c|c|}
\hline No & Article & Author & Journal & PY & TC & $\mathrm{AC}$ \\
\hline 1 & $\begin{array}{l}\text { A population-based perspective of the } \\
\text { hospital incidence and case-fatality rates } \\
\text { of deep-vein thrombosis and pulmonary- } \\
\text { embolism - the Worcester DVT study }\end{array}$ & $\begin{array}{l}\text { Anderson FA et } \\
\text { al. }\end{array}$ & $\begin{array}{l}\text { Archives of Internal } \\
\text { Medicine }\end{array}$ & 1991 & 1771 & 59 \\
\hline 2 & $\begin{array}{l}\text { Trends in the incidence of deep vein } \\
\text { thrombosis and pulmonary embolism - A } \\
25 \text {-year population-based study }\end{array}$ & $\begin{array}{l}\text { Silverstein MD et } \\
\text { al. }\end{array}$ & $\begin{array}{l}\text { Archives of Internal } \\
\text { Medicine }\end{array}$ & 1998 & 1748 & 76 \\
\hline 3 & $\begin{array}{l}\text { The long-term clinical course of acute } \\
\text { deep venous thrombosis }\end{array}$ & Prandoni P et al. & $\begin{array}{l}\text { Annals of Internal } \\
\text { Medicine }\end{array}$ & 1996 & 1539 & 61.6 \\
\hline 4 & $\begin{array}{l}\text { Risk factors for deep vein thrombosis and } \\
\text { pulmonary embolism - A population- } \\
\text { based case-control study }\end{array}$ & Heit JA et al. & $\begin{array}{l}\text { Archives of Internal } \\
\text { Medicine }\end{array}$ & 2000 & 1452 & 69.1 \\
\hline 5 & $\begin{array}{l}\text { A clinical trial of vena caval filters in the } \\
\text { prevention of pulmonary embolism in } \\
\text { patients with proximal deep-vein } \\
\text { thrombosis }\end{array}$ & Decousus H et al. & $\begin{array}{l}\text { New England Journal } \\
\text { of Medicine }\end{array}$ & 1998 & 1112 & 48.4 \\
\hline 6 & $\begin{array}{l}\text { Management of massive and submassive } \\
\text { pulmonary embolism, iliofemoral deep } \\
\text { vein thrombosis, and chronic } \\
\text { thromboembolic pulmonary hypertension }\end{array}$ & Jaff MR et al. & Circulation & 2011 & 1111 & 111 \\
\hline 7 & $\begin{array}{l}\text { A comparison of low-molecular-weight } \\
\text { heparin administered primarily at home } \\
\text { with unfractionated heparin administered } \\
\text { in the hospital for proximal deep-vein } \\
\text { thrombosis }\end{array}$ & Levine $\mathrm{M}$ et al. & $\begin{array}{l}\text { New England Journal } \\
\text { of Medicine }\end{array}$ & 1996 & 963 & 38.5 \\
\hline 8 & $\begin{array}{l}\text { Role of clotting factor-VIII in effect of } \\
\text { von-Willebrand-factor on occurrence of } \\
\text { deep-vein thrombosis }\end{array}$ & Koster T & Lancet & 1995 & 884 & 34 \\
\hline 9 & $\begin{array}{l}\text { Hyperhomocysteinemia as a risk factor for } \\
\text { deep-vein thrombosis }\end{array}$ & denHeijer $\mathrm{M}$ et al. & $\begin{array}{l}\text { New England Journal } \\
\text { of Medicine }\end{array}$ & 1996 & 861 & 34.4 \\
\hline 10 & $\begin{array}{l}\text { Evaluation of D-dimer in the diagnosis of } \\
\text { suspected deep-vein thrombosis }\end{array}$ & Wells PS et al. & $\begin{array}{l}\text { New England Journal } \\
\text { of Medicine }\end{array}$ & 2003 & 764 & 42.4 \\
\hline 11 & $\begin{array}{l}\text { Detection of deep-vein thrombosis by } \\
\text { real-time B-mode ultrasonography }\end{array}$ & $\begin{array}{l}\text { Lensing, AW et } \\
\text { al. }\end{array}$ & $\begin{array}{l}\text { New England Journal } \\
\text { of Medicine }\end{array}$ & 1989 & 740 & 23.1 \\
\hline 12 & $\begin{array}{l}\text { Prevention of pulmonary embolism and } \\
\text { deep vein thrombosis with low dose } \\
\text { aspirin: pulmonary embolism prevention } \\
\text { (PEP) trial }\end{array}$ & O'Brien J et al. & Lancet & 2000 & 710 & 33.8 \\
\hline 13 & $\begin{array}{l}\text { Relative impact of risk factors for deep } \\
\text { vein thrombosis and pulmonary embolism } \\
\text { - A population-based study }\end{array}$ & Heit, JA et al. & $\begin{array}{l}\text { Archives of Internal } \\
\text { Medicine }\end{array}$ & 2002 & 689 & 36.3 \\
\hline 14 & $\begin{array}{l}\text { Value of assessment of pretest probability } \\
\text { of deep-vein thrombosis in clinical } \\
\text { management }\end{array}$ & Wells PS et al. & Lancet & 1997 & 670 & 27.9 \\
\hline 15 & $\begin{array}{l}\text { Predictors of recurrence after deep vein } \\
\text { thrombosis and pulmonary embolism - A } \\
\text { population-based cohort study }\end{array}$ & Heit JA et al. & $\begin{array}{l}\text { Archives of Internal } \\
\text { Medicine }\end{array}$ & 2000 & 610 & 29.1 \\
\hline
\end{tabular}


Table 2 contined

\begin{tabular}{|c|c|c|c|c|c|c|}
\hline 16 & $\begin{array}{l}\text { A prospective-study of the incidence of } \\
\text { deep-vein thrombosis within a defined } \\
\text { urban-population }\end{array}$ & $\begin{array}{l}\text { Nordstrom } \mathrm{M} \text { et } \\
\text { al. }\end{array}$ & $\begin{array}{l}\text { Journal of Internal } \\
\text { Medicine }\end{array}$ & 1992 & 580 & 20 \\
\hline 17 & $\begin{array}{l}\text { Catheter-directed thrombolysis for lower } \\
\text { extremity deep venous thrombosis: Report } \\
\text { of a national multicenter registry }\end{array}$ & $\begin{array}{l}\text { Mewissen MW et } \\
\text { al. }\end{array}$ & Radiology & 1999 & 555 & 25.2 \\
\hline 18 & $\begin{array}{l}\text { Deep-vein thrombosis and the incidence } \\
\text { of subsequent symptomatic cancer }\end{array}$ & Prandoni P et al. & $\begin{array}{l}\text { New England Journal } \\
\text { of Medicine }\end{array}$ & 1992 & 549 & 18.9 \\
\hline 19 & $\begin{array}{l}\text { Comparison of subcutaneous low- } \\
\text { molecular-weight heparin with } \\
\text { intravenous standard heparin in proximal } \\
\text { deep-vein thrombosis }\end{array}$ & Prandoni P et al. & Lancet & 1992 & 544 & 18.8 \\
\hline 20 & $\begin{array}{l}\text { Enhancement by factor-V Leiden } \\
\text { mutation of risk of deep-vein thrombosis } \\
\text { associated with oral-contraceptives } \\
\text { containing 3rd-generation progestagen }\end{array}$ & $\begin{array}{l}\text { Bloemenkamp } \\
\text { KWM et al. }\end{array}$ & Lancet & 1995 & 530 & 20.4 \\
\hline
\end{tabular}

Table 3: The most used trend keywords on deep vein thrombosis

\begin{tabular}{llllll}
\hline Keyword & O & Keyword & O & Keyword & O \\
\hline deep vein thrombosis & 1161 & low molecular weight heparin & 56 & upper extremity deep vein & 29 \\
& & & & thrombosis \\
deep venous thrombosis & 629 & deep vein thrombosis (dvt) & 54 & total hip arthroplasty & 27 \\
pulmonary embolism & 390 & venography & 50 & risk factor & 26 \\
venous thrombosis & 327 & deep and thrombosis & 49 & veins & 25 \\
venous thromboembolism & 317 & postthrombotic syndrome & 49 & mortality & 24 \\
d-dimer & 185 & thromboprophylaxis & 49 & orthopedic surgery & 24 \\
thrombosis & 185 & warfarin & 48 & complications & 23 \\
dvt & 128 & anticoagulants & 46 & fibrinolysis & 23 \\
risk factors & 113 & treatment & 46 & pulmonary thromboembolism & 23 \\
post-thrombotic syndrome & 112 & deep venous thrombosis & 45 & surgery & 23 \\
ultrasonography & 108 & total knee arthroplasty & 44 & hypercoagulability & 22 \\
anticoagulation & 105 & pregnancy & 42 & may-thurner syndrome & 22 \\
diagnosis & 99 & thrombectomy & 38 & screening & 22 \\
thrombolysis & 86 & rivaroxaban & 37 & unfractionated heparin & 22 \\
prophylaxis & 83 & factor v leiden & 36 & doppler ultrasonography & 21 \\
heparin & 82 & thrombolytic therapy & 34 & elderly & 21 \\
low-molecular-weight heparin & 75 & epidemiology & 33 & lower extremity & 21 \\
thromboembolism & 73 & recurrence & 33 & prevention & 21 \\
catheter-directed thrombolysis & 71 & thrombophlebitis & 33 & stroke & 21 \\
thrombophilia & 66 & enoxaparine & 31 & veins, thrombosis & 21 \\
deep-vein thrombosis & 64 & phlebography & 31 & complication \\
ultrasound & 63 & upper extremity & 30 & inferior vena cava & 20 \\
cancer & 60 & trauma & 29 & inflammation & 20 \\
\hline O N & & & & & 20 \\
\hline
\end{tabular}

O: Number of occurrences 


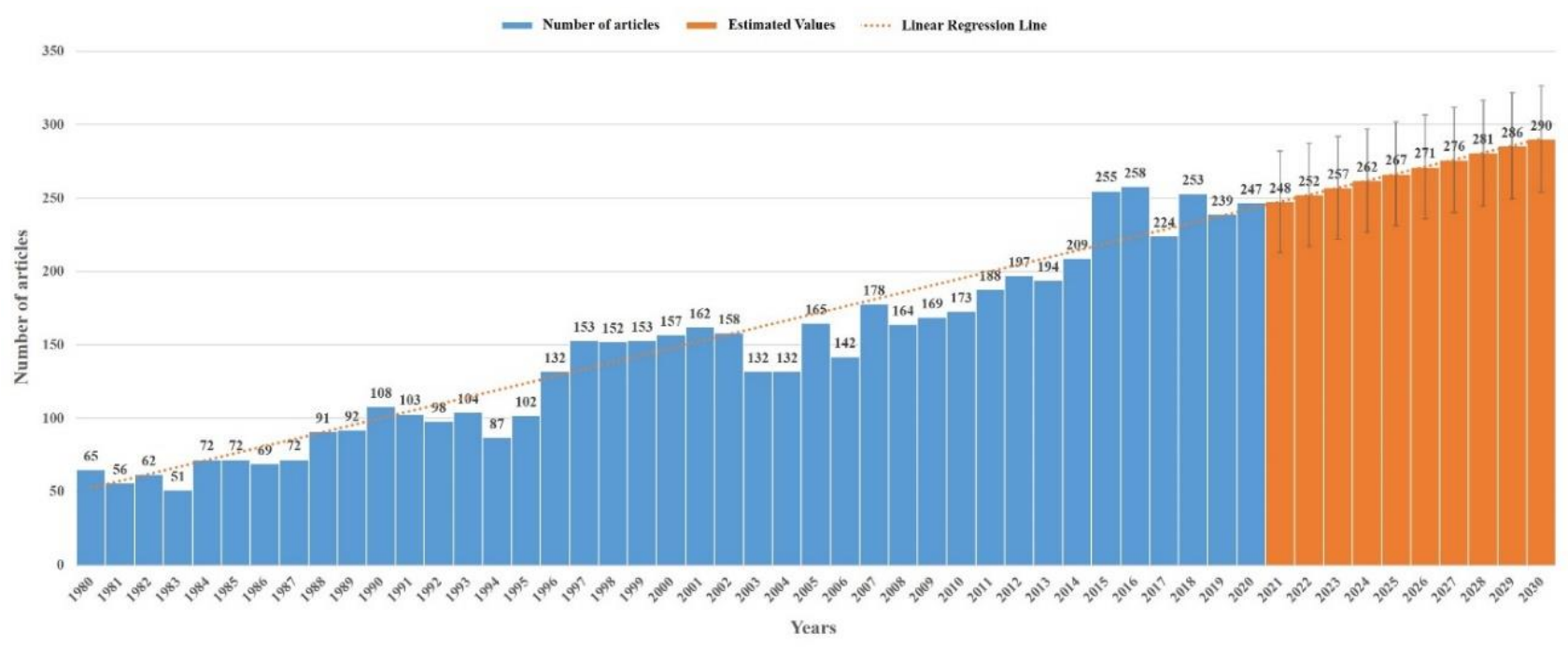

Figure 1: The distribution of articles on deep vein thrombosis by years and estimates of the number of articles that can be published in the coming years together with the regression curve

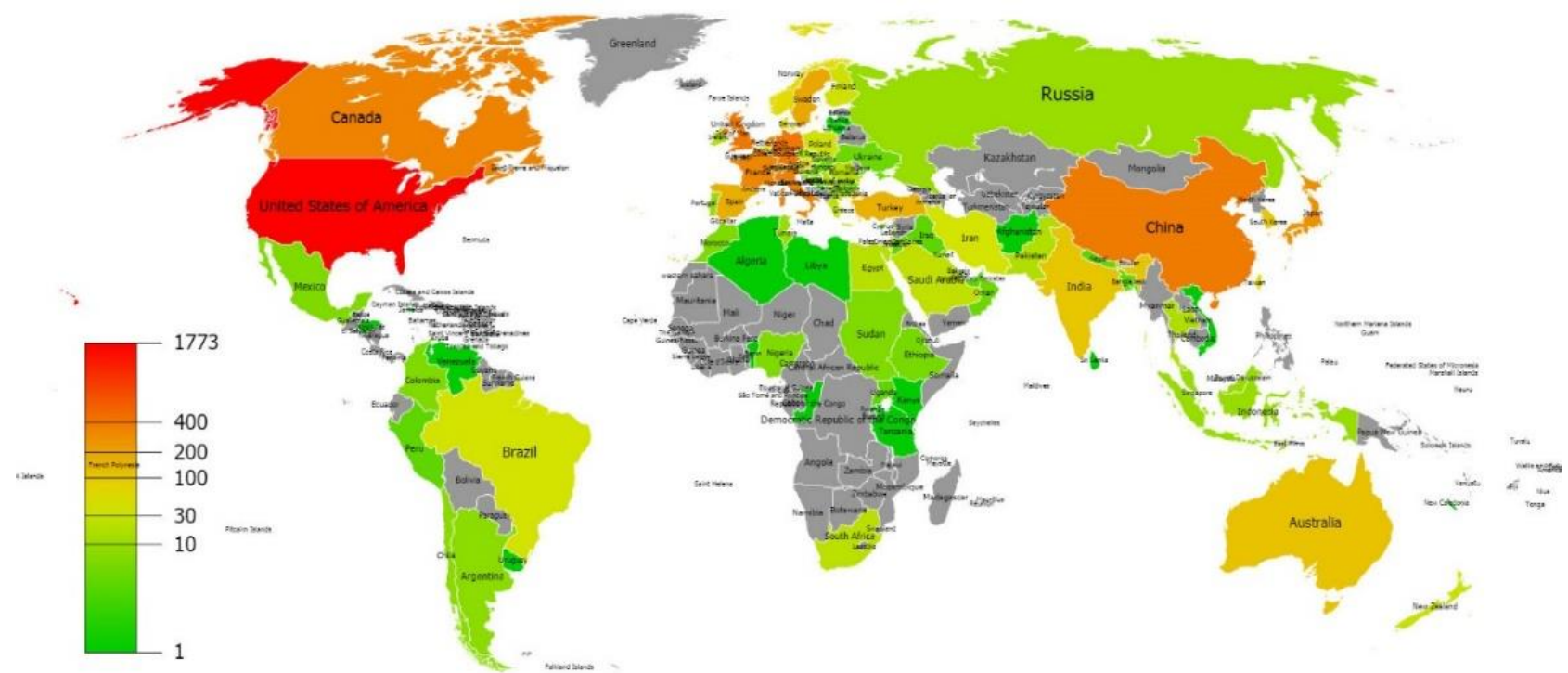

Figure 2: World map showing the distribution of articles on deep vein thrombosis by country Footnote: In the indicator at the bottom left of the figure, the article productivity of countries increases from green to red. 

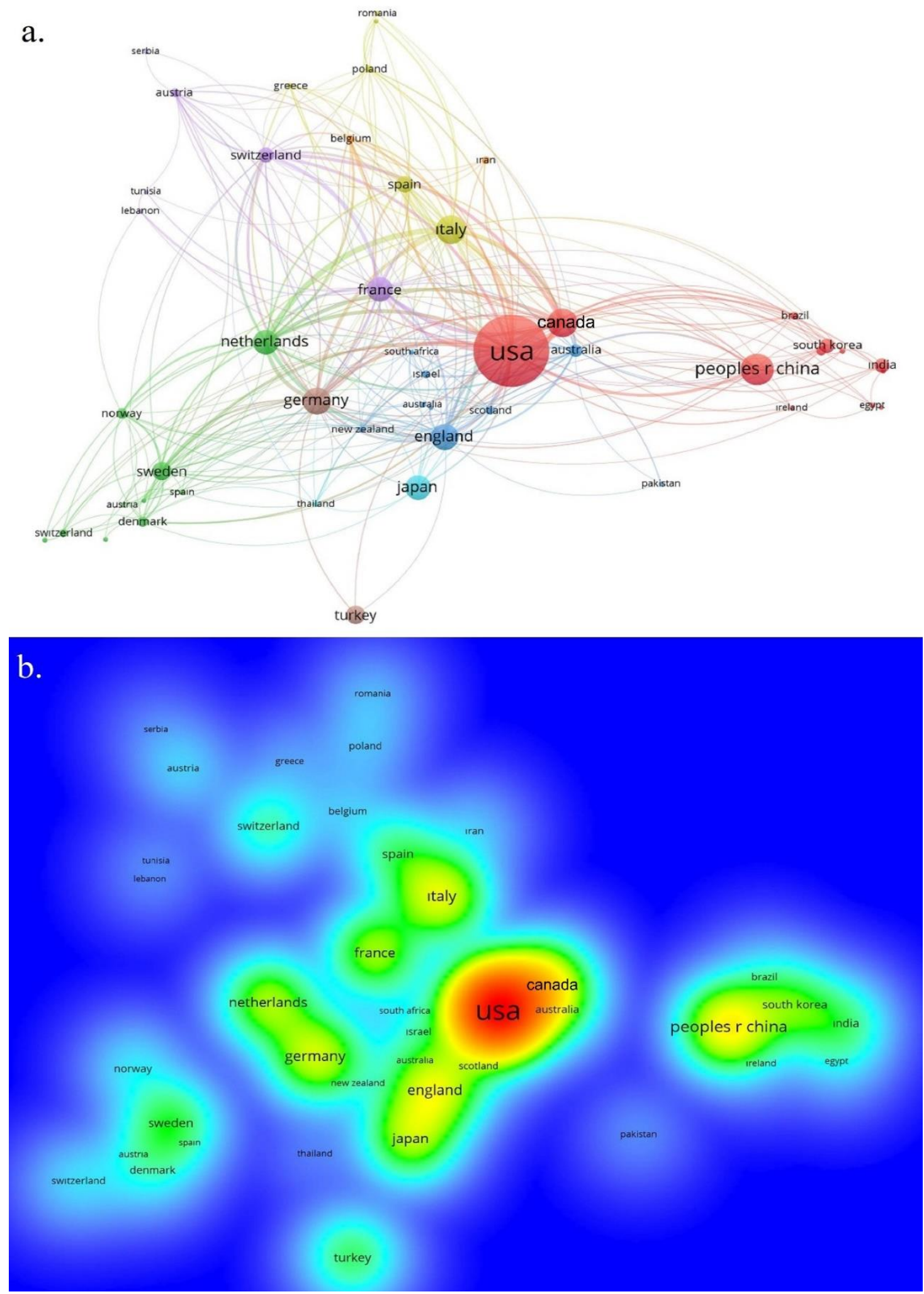

Figure 3: a. Network visualization map for international collaboration of world countries on deep vein thrombosis Footnote: The colors show different clusters. The size of the circle area shows that the number of articles produced is more. The thick lines show that the relationship is strong. b. Density map of world countries on article productivity on deep vein thrombosis. Footnote: The higher the articles of the countries, the closer the color of the point is to red. 


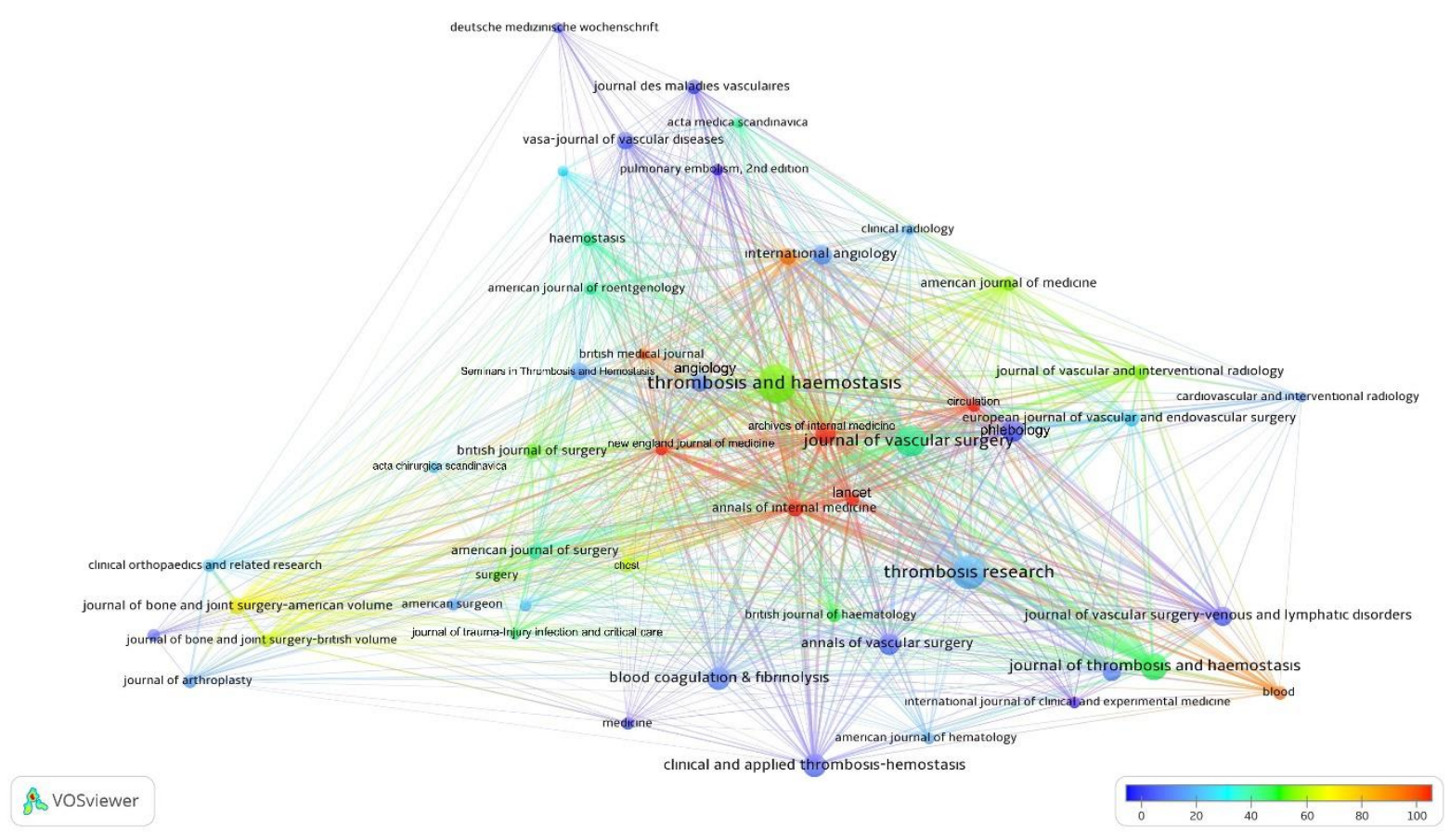

Figure 4: Network visualization map for citation analysis of journals that produce publications on deep vein thrombosis Footnote: A color bar was shown in the bottom right corner of the map. The colors show the average number of citations per article published by journals. For example, the average number of citations for blue-colored journals is below 10 , while the average number of citations for red-colored journals is over 100, and the journal has a higher impact factor.

\section{A vosviewer}

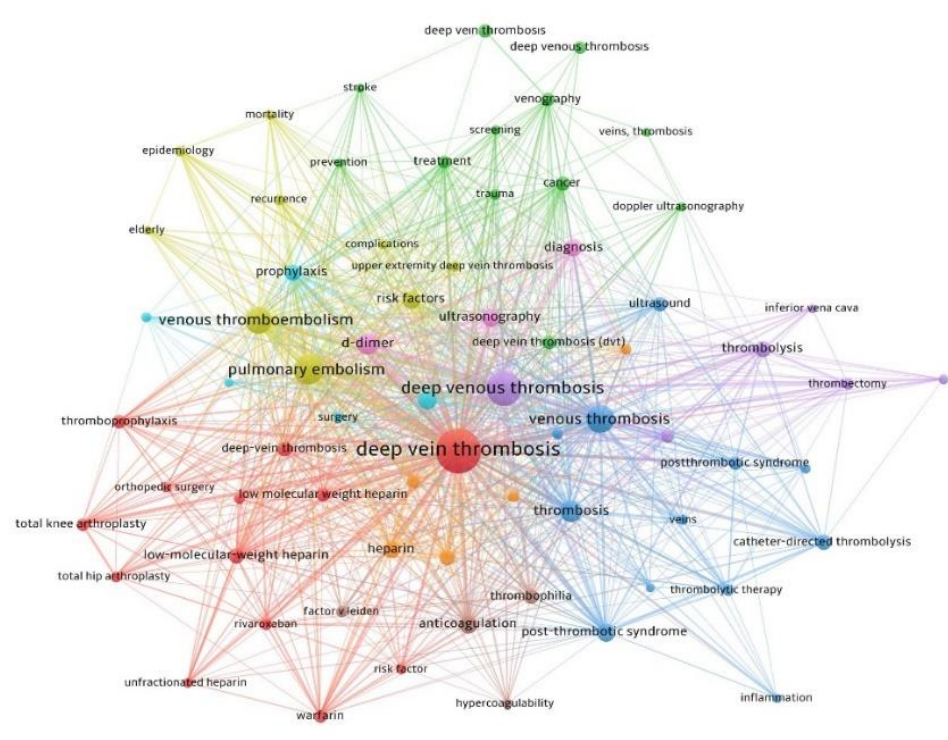

Figure 5: Network visualization map for cluster analysis based on keyword analysis on deep vein thrombosis Footnote: The colors indicate the clusters, the size of the circle area indicates that the number of articles produced is greater, and the thickness of the lines indicates the strength of relationship 

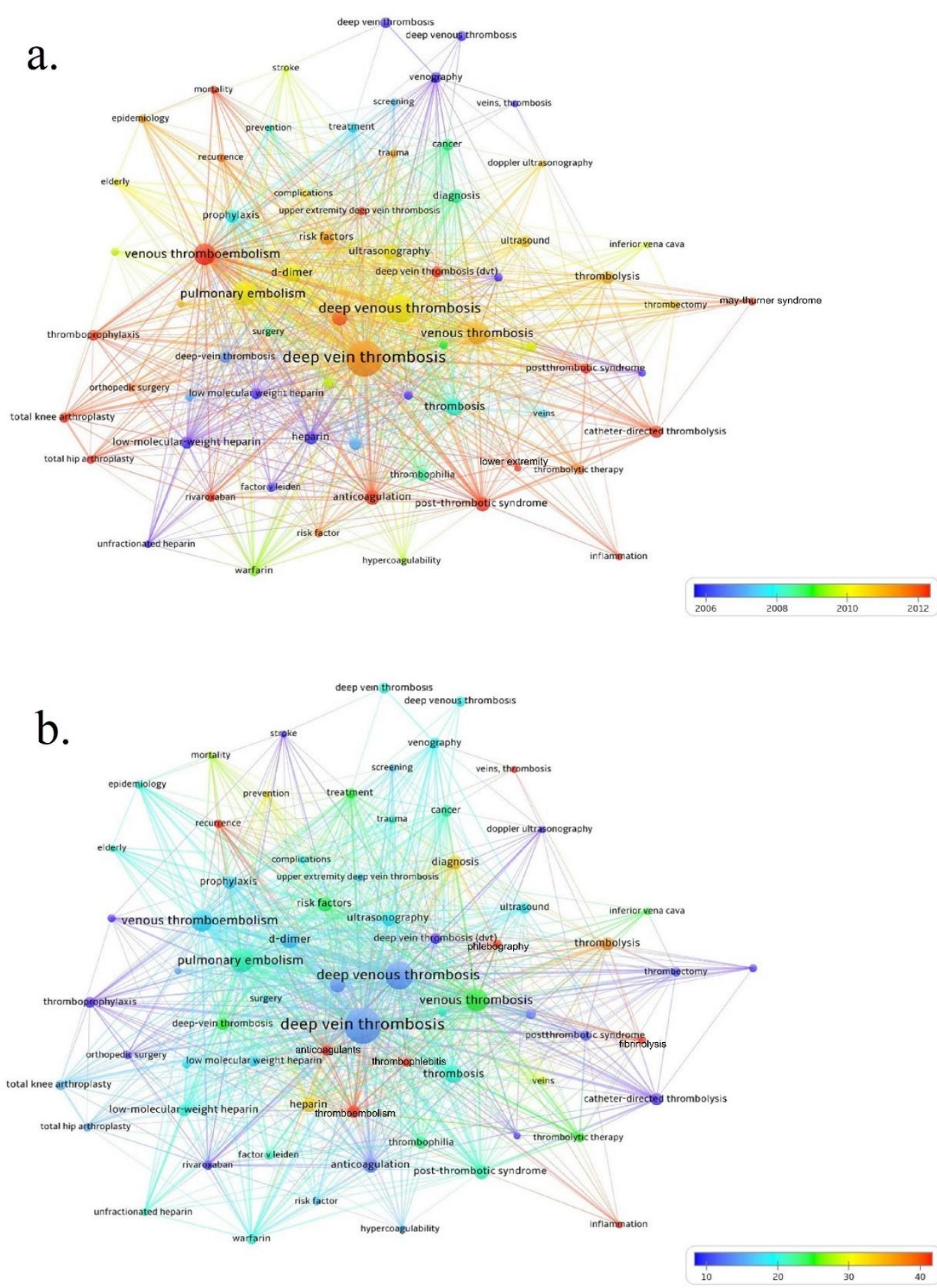

Figure 6a: Network visualization map showing trend keyword analysis results on deep vein thrombosis Footnote: A color bar was shown in the bottom right corner of the map. Indicator shows current articles from blue to red, the size of the circle area indicates that the number of articles produced is greater $\mathbf{b}$. Network visualization map showing the most cited keyword analysis results on deep vein thrombosis

Footnote: A color bar was shown in the bottom right corner of the map. The number of citations from blue to red (bluegreen-yellow-red) increases, the size of the circle area indicates that the number of articles produced is greater 


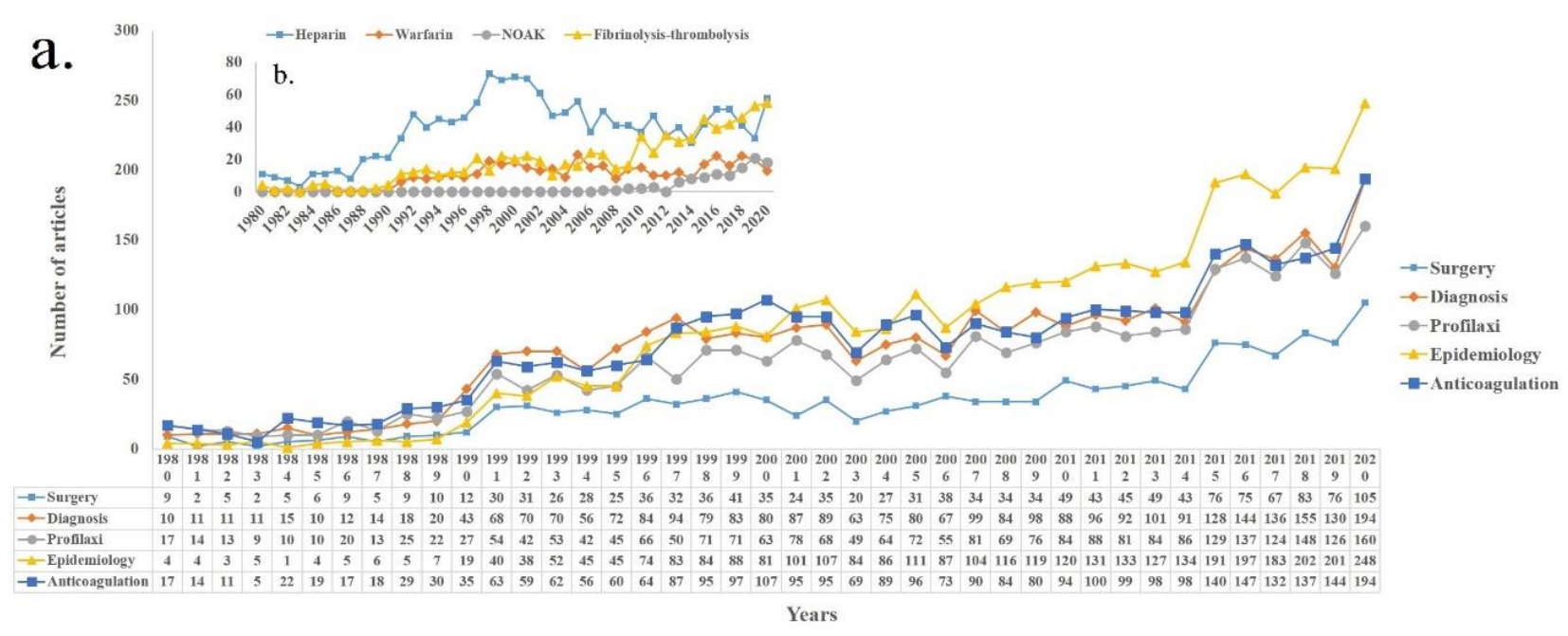

Figure 7a: The distribution of studies over the years by clinical grouping. b. The distribution of studies over the years by medical treatment groups.

\section{DISCUSSION}

There is a significant increase in the number of publications on DVT within years. Between 1980 and 1995, 82 articles per year were published on an average, 154 articles per year on an average between 1996 and 2009, and 222 articles per year on an average between 2010 and 2020. According to the findings of the regression analysis, the increasing trend will continue linearly, and an average of 269 articles per year will be published between 2020 and 2030. Of the top 20 most active countries in terms of productivity in publications on DVT, 17 were developed countries (USA, UK, Germany, Italy, Canada, France, Netherlands, Japan, Sweden, Switzerland, Spain, Australia, South Korea, Austria, Denmark, Norway, and Taiwan) and only 3 were developing countries (China, Turkey, and India). The leading positions of developed countries in publication productivity suggest that productivity in publications on DVT is directly related to economic power. Correlation analysis results, which are statistically significant between article productivity and certain development indicators, support this inference. When the collaborations between countries were assessed, it may be said that geographical neighborhood often plays a role in the collaborations. Journals that published the highest numbers of articles were Thrombosis and Haemostasis, Thrombosis Research, Journal of Vascular Surgery, Journal of Thrombosis and Haemostasis, Clinical and Applied Thrombosis/Hemostasis, and Blood Coagulation \& Fibrinolysis, respectively. Authors who intend to publish on this topic can consider these journals. Journals that are active on DVT (that have produced 20 and more articles) are evaluated as per the number of citations received per article: New England Journal of Medicine, Lancet, Archives of Internal Medicine, Annals of Internal Medicine, Circulation, British Medical Journal, Blood, and Radiology were the leading ones. The highest total number of citations on DVT was received by the article by Anderson et al. (1991) titled "A population-based perspective of the hospital incidence and case-fatality rates of deep-vein thrombosis and pulmonary-embolism - the Worcester DVT study" (7). The study that received the second highest number of citations was the study by Silverstein et al. (1998) titled "Trends in the incidence of deep vein thrombosis and pulmonary embolism - A 25-year 
population-based study" (5). The most cited studies after these two studies were the studies by Prandoni et al. (1996) and Heit et al. (2000) (19,25). These top four most cited studies were published in Archives of Internal Medicine and Annals of Internal Medicine. When articles were evaluated based on average citations per year, the highest impact article with the highest average number of citations was the article by Jaff et al (2011) titled "Management of massive and submassive pulmonary embolism, iliofemoral deep vein thrombosis, and chronic thromboembolic pulmonary hypertension" published in Circulation (26). The highest impact articles following the aforementioned in terms of the average number of citations were the articles by Silverstein et al. (1998), Heit et al. (2000), Prandoni et al. (1996), Anderson et al. (1991), and Enden et al. (2012) $(5,7,19,25,27)$. According to the co-citation analysis, researchers most often cited the studies by Rabinov (1972), Lensing (1989), Prandoni (1996), Anderson (1991), Wells (1997), Mewissen (1999), Koopman (1996), Kearon (2012), and Levine (1996) in the reference sections of their articles $(7,17-24)$. We may say that these publications should be the first ones to be read by the researchers who are interested in DVT or preparing for a new study on DVT. As a result of the cluster keyword analysis, nine main clusters were formed. It may be said that clusters were generally divided into such topics as complications, drugs, imaging methods, and epidemiology. When the most used keywords on DVT (>20 times) were analyzed according to their publication years, the trend keywords used in recent years were anticoagulants, rivaroxaban, recurrence, mortality, total knee arthroplasty, total hip arthroplasty, post-thrombotic syndrome, catheterdirected thrombolysis, and May-Thurner syndrome. The keywords used in the most cited articles were recurrence, thrombophlebitis, anticoagulants, thromboembolism, phlebography, fibrinolysis, and inflammation. We have not come across any comprehensive bibliometric studies on DVT in the literature. Tian et al. (2020) conducted a bibliometric analysis of 1779 studies on venous thromboembolism in children published between 1988 and 2019 (28). In that study, DVT, pulmonary embolism, and venous thromboembolism were evaluated together. However, this study focuses solely on DVT.

In this study, we evaluated the studies made by reading the abstract sections of all studies on DVT between 1980 and 2020 in 5 groups. In this way, we investigated in which direction the studies have changed clinically. While a limited number of studies were conducted on the epidemiology, diagnosis, prophylaxis, and treatment of DVT until the 90s and the number of studies started to increase significantly after this date. Studies carried out until the 2000s were mostly on the diagnosis and treatment of DVT. As is known, the main component of DVT treatment is anticoagulation therapy. Since the beginning of the 2000s, studies have been carried out on the epidemiology of DVT rather than diagnosis and treatment. Today, the effectiveness of the current diagnosis and treatment methods used in DVT has been demonstrated to a great extent. Since a more effective treatment method has not been found over the years; the number of studies on the causes, pathophysiology, and prevention of DVT is increasing every year. When the medical treatment is examined, it is seen that heparins were the group with the most studies until the 2000s. After the 2000s, with the developments in medicine and interventional methods, it is seen that there has been a significant increase on fibrinolytic and thrombolytic treatments to treat DVT acutely and rapidly. After the 2010s, with the discovery of new oral anticoagulants and the introduction of DVT into treatment guidelines, the number of studies on this subject has been increasing gradually. It is an inevitable fact that studies on NOACs will increase rapidly in the coming years.

This study can be said to be more comprehensive than the aforementioned study in many aspects such as the number of articles analyzed, the time period examined, citation and co-citation analyses, cluster analysis, trend KüTFD | 581 
topics analysis, and correlation analysis. Because publications made before 1980 were not indexed in the WoS database, we could not reach the publications on DVT made before 1980, which may be referred to as the first limitation of the study. The second limitation of the study is that the literature review was performed using the WoS database only; note that Pubmed and Scopus databases were not reviewed. The reason why Pubmed database was not used is that citation analysis cannot be performed. The reason why Scopus database was not used is that it includes low impact journals. Because journals with high impact factor are indexed in the Wos database, WoS is a more reliable database than other databases in terms of citations $(29,30)$. Furthermore, if more than one database is used in such studies where a high number of articles are analyzed, the same article is included in the analysis more than once, and the reliability of the results is affected. WoS database was preferred in many bibliometric studies conducted in recent years $(8-15)$.

Although many studies have been conducted on DVT to date, there are many sub-titles about DVT that need to be clarified. As a result of our study, it is predicted that the number of studies on DVT will increase over the years. Although studies are mostly carried out on the treatment of DVT today, there are still parameters that need to be clarified in epidemiology, diagnosis, and prophylaxis, so the number of studies on these subjects is too large to be underestimated.

In conclusion, this study will be a useful guide for scientists and clinicians about the global outcomes of DVT.

Conflict of Interest: The authors declare that he has no conflict of interest.

Support and Acknowledgment: None. The study had no funding source.
Researchers' Contribution Rate Statement: Idea/Planning: SÖ, MEE. Analysis: SÖ, MEE Data collection/Data processing: SÖ Writing: SÖ, MEE Review: SÖ, MEE Approval: SÖ

Ethics Committe Aproval: This study does not contain any studies with human participants or animals performed by any of the authors.

Informed Consent: Formal consent is not required for this type of study.

\section{REFERENCES}

1. Bagot CN, Arya R. Virchow and his triad: a question of attribution. Br J Haematol. 2008;143(2):180-90.

2. Kumar DR, Hanlin E, Glurich I, Mazza JJ, Yale SH. Virchow's contribution to the understanding of thrombosis and cellular biology. Clin Med Res. 2010;8(3-4):168-72.

3. Cushman M. Epidemiology and risk factors for venous thrombosis. Semin Hematol. 2007;44(2):629.

4. National Institute for Health and Care Excellence Venous Thromboembolism in over 16s; reducing the risk of hospital-acquired deep vein thrombosis or pulmonary embolism. NICE guideline [NG89]. London: NICE, 2018. Accessed date: 20 December 2021: www.nice.org.uk/guidance/ng89.

5. Silverstein MD, Heit JA, Mohr DN, Petterson TM, O'Fallon WM, Melton LJ. Trends in the incidence of deep vein thrombosis and pulmonary embolism: a 25-year population-based study. Arch Intern Med. 1998;158(6):585-93.

6. Crous-Bou M, Harrington LB, Kabrhel C. Environmental and genetic risk factors associated with venous thromboembolism. Semin Thromb Hemost. 2016;42(8):808-20.

7. Anderson FA, Wheeler HB, Goldberg RJ, Hosmer DW, Patwardhan NA, Jovanovic B et al. A 
population-based perspective of the hospital incidence and case-fatality rates of deep vein thrombosis and pulmonary embolism. The Worcester DVT Study. Arch Intern Med. 1991;151(5):933-8.

8. Gölpınar M, Demir E. Global research output of the cerebellum: Yesterday, today, and tomorrow. J Anat Soc India. 2020;69(3):155-65.

9. Kiraz M, Demir E. A Bibliometric analysis of publications on spinal cord injury during 1980-2018. World Neurosurg. 2020;136:e504-e513.

10. Muslu U, Demir E. Development of rhinoplasty: yesterday and today. Med Sci. 2019;23(97):294-301.

11. Yıldırım E, Demir E. Comparative bibliometric analysis of fertility preservation. Ann Med. Ann Med Res 2019;26(8):1622-8.

12. Doğan G, İpek H. The development of necrotizing enterocolitis publications: a holistic evolution of global literature with bibliometric analysis. Eur $\mathbf{J}$ Pediatr Surg. 2020;30(3):293-303.

13. Demir E, Akmeşe ÖF, Erbay H, Taylan-Özkan A, Mumcuoğlu KY. Bibliometric analysis of publications on house dust mites during 1980-2018. Allergol Immunopathol (Madr). 2020;48(4):374-83.

14. Doğan G, Karaca O. A bibliometric analysis of the field of anesthesia during 2009-2018: A bibliometric analysis of anesthesia. Braz J Anesthesiol. 2020;70(2):140-52.

15. Doğan G, İpek H. The evolution of hypospadias publications: A bibliometric approach. Rev Int Androl. 2021;19(4):224-33.

16. van Eck NJ, Waltman L. Software survey: VOSviewer, a computer program for bibliometric mapping. Scientometrics. 2010;84(2):523-38.

17. Rabinov K, Paulin S. Roentgen diagnosis of venous thrombosis in the leg. Arch Surg. 1972;104(2):13444.
18. Lensing AW, Prandoni P, Brandjes D, Huisman PM, Vigo M, Tomasella G et al. Detection of deep-vein thrombosis by real-time B-mode ultrasonography. $\mathrm{N}$ Engl J Med. 1989;320(6):342-5.

19. Prandoni P, Lensing AW, Cogo A, Cuppini S, Villalta S, Carta $\mathrm{M}$ et al. The long-term clinical course of acute deep venous thrombosis. Ann Intern Med. 1996;125(1):1-7

20. Wells PS, Anderson DR, Bormanis J, Guy F, Mitchell M, Gray L et al. Value of assessment of pretest probability of deep-vein thrombosis in clinical management. Lancet. 1997;350(9094):17958.

21. Mewissen MW, Seabrook GR, Meissner MH, Cynamon J, Labropoulos N, Haughton SH. Catheterdirected thrombolysis for lower extremity deep venous thrombosis: report of a national multicenter registry. Radiology. 1999;211(1):39-49.

22. Koopman MM, Prandoni P, Piovella F, Ockelford PA, Brandjes DP, Van Der Meer J et al. Treatment of venous thrombosis with intravenous unfractionated heparin administered in the hospital as compared with subcutaneous low-molecularweight heparin administered at home. N Engl J Med. 1996;334(11):682-7.

23. Kearon C, Akl EA, Comerota AJ, Prandoni P, Bounameaux H, Goldhaber SZ et al. Antithrombotic therapy for VTE disease: Antithrombotic Therapy and Prevention of Thrombosis, 9th ed: American College of Chest Physicians Evidence-Based Clinical Practice Guidelines. Chest. 2012;141(2 Suppl):e419S-e496S.

24. Levine M, Gent M, Hirsh J, Leclerc J, Anderson D, Weitz J et al. A comparison of low-molecular-weight heparin administered primarily at home with unfractionated heparin administered in the hospital for proximal deep-vein thrombosis. N Engl J Med. 1996;334(11):677-81. 
25. Heit JA, Silverstein MD, Mohr DN, Petterson TM, O'Fallon, WM, Melton LJ. Risk factors for deep vein thrombosis and pulmonary embolism: a populationbased case-control study. Arch Intern Med. 2000;160(6):809-15.

26. Jaff MR, McMurtry MS, Archer SL, Cushman M, Goldenberg N, Goldhaber SZ et al. Management of massive and submassive pulmonary embolism, iliofemoral deep vein thrombosis, and chronic thromboembolic pulmonary hypertension: a scientific statement from the American Heart Association. Circulation. 2011;123(16):1788-830.

27. Enden T, Haig Y, Kløw NE, Slagsvold CE, Sandvik L, Ghanima W et al. Long-term outcome after additional catheter-directed thrombolysis versus standard treatment for acute iliofemoral deep vein thrombosis (the CaVenT study): a randomised controlled trial. Lancet. 2012;379(9810):31-38.

28. Tian L, Zhang Y, Zeng J, Wang L, Gao H, Su Y et al. A bibliometric analysis of publications on venous thromboembolism in children from 1988 to 2019. Medicine (Baltimore). 2020;99(20):e20114.

29. Demir E, Comba A. The evolution of celiac disease publications: a holistic approach with bibliometric analysis. Ir J Med Sci. 2020;189(1):267-76.

30. Demir E, Yaşar E, Özkoçak V, Yıldırım E. The evolution of the field of legal medicine: A holistic investigation of global outputs with bibliometric analysis. J Forensic Leg Med. 2020;69:101885. 